\title{
Economics
}

\section{Tourism a Way to Bring Social Change: A Case Study of Jim- Corbett National Park}

\author{
Abha Agrawal ${ }^{1,}$, , Malini Shrama ${ }^{2}$ \\ ${ }^{1}$ Government Post Graduate College Syaldey, Kumaun University, Uttarakhand, India \\ ${ }^{2}$ Government Post Graduate College Kashipur, Kumaun University, Uttarakhand, India
}

Email address:

abha6040@gmail.com (A. Agrawal), malinisharma810@gmail.com (M. Sharma)

${ }^{*}$ Corresponding author

To cite this article:

Abha Agrawal, Malini Shrama. Tourism a Way to Bring Social Change: A Case Study of Jim- Corbett National Park. Economics. Vol. 10, No. 1, 2021, pp. 1-7. doi: 10.11648/j.eco.20211001.11

Received: September 18, 2020; Accepted: December 29, 2020; Published: January 12, 2021

\begin{abstract}
Tourism is generally described for its sustainability, economic viability as well as expansion and a means for restoration of happiness but few may have thought tourism as catalyst to bringing social equilibrium via social stratification. Tourism just like socialism rests in ending any kind of barriers among the citizens of the world. Tourism is a way of living, a way of learning, a way to thrive, a way to shift the frontiers of universal fraternity not only this, is the only way, to put an end in predatory, orthodox, fundamentalist thinking. Present study draws attention towards this. When one person feels urbanized, he wants to be socialized, next he starts moving to and fro, from inbound to outbound tourism and the level of satisfaction goes on in upward direction. Not only level of satisfaction but also mental stratification towards the existence, life-expectancy and expansion of one -self starts blinking. More advanced, urbanized, and developed a nation is; more uniform its citizens would be. The whole paper has been divided between three sections: section one starts with brief introduction, section II consists of objective, hypothesis and methodology, section III presents the analysis while section IV deals in with findings of the research work.
\end{abstract}

Keywords: Inbound, Outbound, Jim Corbett, Intercept, Family Size, Macro Level

\section{Introduction}

Tourism just like socialism rests in ending any kind of barriers among the citizens of the world. Tourism is a way of living, a way of learning, a way to thrive, a way to shift the frontiers of universal fraternity not only this, is the only way, to put an end in predatory, orthodox, fundamentalist thinking. The underpinning human rests in knowing and analyzing various social variables those inhibit healthy global growth. Human development report 2019 brings in new generation of inequalities [1] on the fore. One of the five key issues is low intergenerational mobility of income results in low human development index. The same judgment can be arrived with the people and their countries in terms of tourism. Tourism can cast its effect on dvelopment level the way in which urbanization does. Tourism is supreme form of urbanization. When one person feels urbanized, he wants to be socialized, next he starts moving to and fro, from inbound to outbound tourism and the level of satisfaction goes on in upward direction. Not only level of satisfaction but also mental stratification towards the existence, life-expectancy and expansion of one -self starts blinking. More advanced, urbanized, and developed a nation is more uniform its citizens would be. The ultimate goal of socialism rests here. "All kinds of social customs and economic practices, affecting the distribution of wealth and of economic rewards and penalties, which we now maintain at all costs, however distasteful and unjust they may be in themselves, because they are tremendously useful in promoting the accumulation of capital, we shall then be free, at last, to discard. The strenuous purposeful money-makers may carry all of us along with them into the lap of economic abundance. But it will be those peoples, who can keep alive, and cultivate into a fuller perfection, the art of life itself and do not sell 
themselves for the means of life, who will be able to enjoy the abundance when it comes" [2]. All our great philosophers and economists from Adam Smith, Hegel, Marx [3-5] have emphasized on the convergence of social beings into moral beings.

\section{Methods}

\subsection{Objectives}

Social stratification refers to the way people are ranked and ordered in society. Racism, sexism, heterosexism and education plays a vital role in social stratification. This stratification primarily occurs as a result of socioeconomic status in which a hierarchy determines the groups most likely to gain access to financial resources and forms of privilege. [6].

In this milieu objective of the present research paper is:

1. To know whether tourism can act as catalyst to social change.

2. Changes in economic level alone can boost tourism growth.

\subsection{Methodology}

The present piece of work with 100 respondents- twenty five foreign tourists and seventy five domestic tourists (from other states) were interviewed: at random over a period of nine months from November 2017 to July 2018, which are the months for peak tourism; in Jim Corbett National Park. A structured and validated questionnaire was used to interview the tourists to check their behavior across levels of income so that the discrepancies found, if any, can be analyzed in broader perspectives.

An attempt has been made to find out the association of tourist expenditure and annual income with the type of tourist. Analysis of Variance (ANOVA) is used to explain the main effects of factors and the interaction effect of the factor on the per day expenditure of the tourists. For Analysis purpose SPSS software version 20 was used.

\subsection{Hypotheses: To Be Tested Were}

Ho1: Type of tourist will have no significant effect on tourist expenditure.

Ho2: Annual income will have no significant effect on tourist expenditure.

Ho3: Type of tourist and Annual Income will have significant effect on tourist expenditure

\section{Review of Literature}

In 1759, Adam Smith published The Theory of Moral Sentiments in which he has thrown light on punishment, justice, virtues, prudence, constancy, morality, beneficence and social freedom. The literary work mainly concerned how human morality depends on sympathy between the agent and spectator. It shows that our moral ideas and actions are a product of our very nature as social creatures. It argues that this social psychology is a better guide to moral action than is reason. It identifies the basic rules of prudence and justice that are needed for society to survive, and explains the additional, beneficent, actions that enable it to flourish. As we grow from childhood to adulthood, we each learn what is and is not acceptable to other people. Morality stems from our social nature. [3]

Social stability has many virtues it is true. But being unable to change for the better is not one of them. Adopting a Hegelian-Aristotelian perspective; viewing society as a quasi-organism and social concepts as quasi-autonomous ideas we might hazard that the 'dialectic of history' can get stuck instead of continuing to unfold its internal logic. We might also suppose that the organic development of the 'dialectic of history' can get prematurely arrested leaving a civilization or a society in a permanent state of adolescence. It is rather more plausible that certain stabilising mechanisms have been incorporated into the system that make it unable to change on any large scale, so it is inhibited from moving to any further stage of development. In Hegelian dialectical terms each of these big ideas and institutions of society must be living and moving ideas that continually develop and grow in our understanding and their application. Do we really want to remain stuck with a 19 th century concept of Freedom rather than continuing to develop and expand it? [7].

So neither GDP nor EMP is the barometer of economic health rather its co-union of GDP and EMP. For the economies which are suffering from unemployment problem: a combination of raising the economic- freedom, managerial efficiency and either raising marriage age or social -freedom ought to be followed. [8]

A careful reading of 2020's World Happiness Report suggests that smaller, urbanized nations have the edge on happiness. A higher quality of social environment not only raises the average quality of lives directly, but also reduces their inequality. A strong social environment thus allows people to be more resilient in the face of life's hardships. Social environment means social- support and social freedom [9] i.e. evolving trust in institutions and socialconnections.

\section{Result}

\subsection{Topology of the Land of GODs in Uttarakhand}

The state ranks $19^{\text {th }}$ in terms of area coverage and $20^{\text {th }}$ most populous state in India. Nestled in the lap of Himalayas the state has $70 \%$ of area under forest cover which makes it an ideal destination for the natural traditional and new emerging avenues of tourism. Natural beauty abounds here in the form of glaciers, dense forests and rivers making it an ideal destination for adventure, leisure and ecotourism, yoga and wellness activities. It's topographical diversity makes it a heavenly place.

The ancient cultural and traditions of Uttarakhand are manifested in the music, dance, art forms and religious customs. The people of Uttarakhand share a divine bondage with the awe inspiring Himalayas. A journey to Uttarakhand is not only a religious and an adventurous journey, it is spiritual as well. 
Uttarakhand is a land of Hindu temples. There are a number of holy Hindu shrines. Thousands of Hindu devotees visit the holy Ganga in hopes of attaining salvation and purification. The Char- Dhams are the most auspicious pilgrimage places. The Kumbh -Mela that is held after every twelve years witnesses some of the largest gatherings of devotees to be seen anywhere in the whole world.

Uttarakhand is endowed with a unique and diverse range of biodiversity. From the snowbound peaks of the Himalayas to the moist Alpine scrub, sub Alpine forests, dry - temperate and moist- temperate forests to moist deciduous forests, the diversity is unique. Uttarakhand has a diversity of flora and fauna. Due to its mountainous topography, flowing rivers and glaciers, Uttarakhand also offers many adventure tourism opportunities in the form of trekking, skiing, paragliding, camping, angling, mountaineering and rock climbing. [10]

Table 1. Uttarakhamd: sector-wise Contribution inSGDP(at current prices)

\begin{tabular}{lll}
\hline Uttarakhand & & \\
\hline Sector-wise contribution in SGDP & & \\
\hline at current prices & & $\mathbf{2 0 1 8 - 1 9}$ \\
\hline Sector & $\mathbf{2 0 1 1 - 1 2}$ & 10.57 \\
\hline Primary & 14 & 48.93 \\
Secondary & 52.13 & 40.50 \\
Tertiary & 33.88 & 100 \\
Total GSDP & 100 & \\
\hline
\end{tabular}

Source: Directorate of Economics and Statistics, Planning Department, Uttarakhand. [11]

Table 2. State-wise Contribution of Tourism to Indian Economy (2015-16).

\begin{tabular}{llll}
\hline \multirow{2}{*}{ States } & Gross Value added (GVA) & Tourism Direct Gross Valvue & Share of TDGVA in GVA \\
\cline { 3 - 4 } & at basic prices (Rs.Lakh) & Added (TDGVA in Rs. lakh & Driect (\%) \\
\hline A \& N Island & 418325 & 30197 & 7.22 \\
Andhra Pradesh & 48166626 & 1856387 & 3.85 \\
Delhi & 22154351 & 937036 & 4.23 \\
Goa & 2958592 & 218577 & 7.39 \\
Jammu \& Kashmir & 4912896 & 193346 & 3.94 \\
Kerala & 24164435 & 1130801 & 4.68 \\
Karnataka & 34348035 & 1097409 & 3.19 \\
Maharashtra & 87031584 & 2850738 & 3.28 \\
Rajasthan & 26989445 & 1003602 & 3.72 \\
Tamil Nadu & 48808673 & 1895119 & 3.07 \\
Uttar Pradesh & 53178944 & 1820425 & 3.88 \\
Uttarakhand & 7181027 & 292411 & 4.59 \\
\hline
\end{tabular}

Table 2. Continued.

\begin{tabular}{lllll}
\hline \multirow{2}{*}{ States } & State Employment (in & Tourism Direct Employment (in & \multicolumn{2}{l}{ Share of Tourism Employment to Total State Employment } \\
\cline { 3 - 4 } & lakh numbers) & lakh numbers) & Direct (\%) \\
\hline A \& N Island & 1.51 & 0.19 & 12.85 \\
Andhra Pradesh & 479.35 & 21.65 & 4.52 & 30.95 \\
Delhi & 52.4 & 4.49 & 8.58 & 17.33 \\
Goa & 4.68 & 0.74 & 15.86 \\
Jammu \& Kashmir & 60.9 & 2.12 & 3.48 & 17.64 \\
Kerala & 142.43 & 14.07 & 9.88 \\
Karnataka & 301.96 & 15.55 & 5.15 & 32.77 \\
Maharashtra & 548.84 & 31.43 & 5.73 \\
Rajasthan & 331.48 & 8.9 & 2.68 \\
Tamil Nadu & 353.12 & 20.42 & 5.78 \\
Uttar Pradesh & 758.35 & 26.14 & 3.45 \\
Uttarakhand & 46.91 & 1.6 & 3.42 \\
\hline
\end{tabular}

Source: NCAER Computations (Regional Tourism Satellite Account Uttarakhand, 2015-16) [12]

The economy of the State has been largely dominated by the services sector; including tourism, which contributes over $40 \%$ to the total Gross State Domestic Product from 20112012 to 2016-17 (table 1). As per a recent report by World Tourism and Travel Council (WTTC), India has been pegged as $7^{\text {th }}$ largest tourism economy globally and has forecasted it to grow by $7 \%$ between 2017 and 2027. Uttarakhand is expected to match this trend in terms of tourist arrivals. Uttrakhand holds 7 th position in terms of

TDGVA in GVA (table 2). 


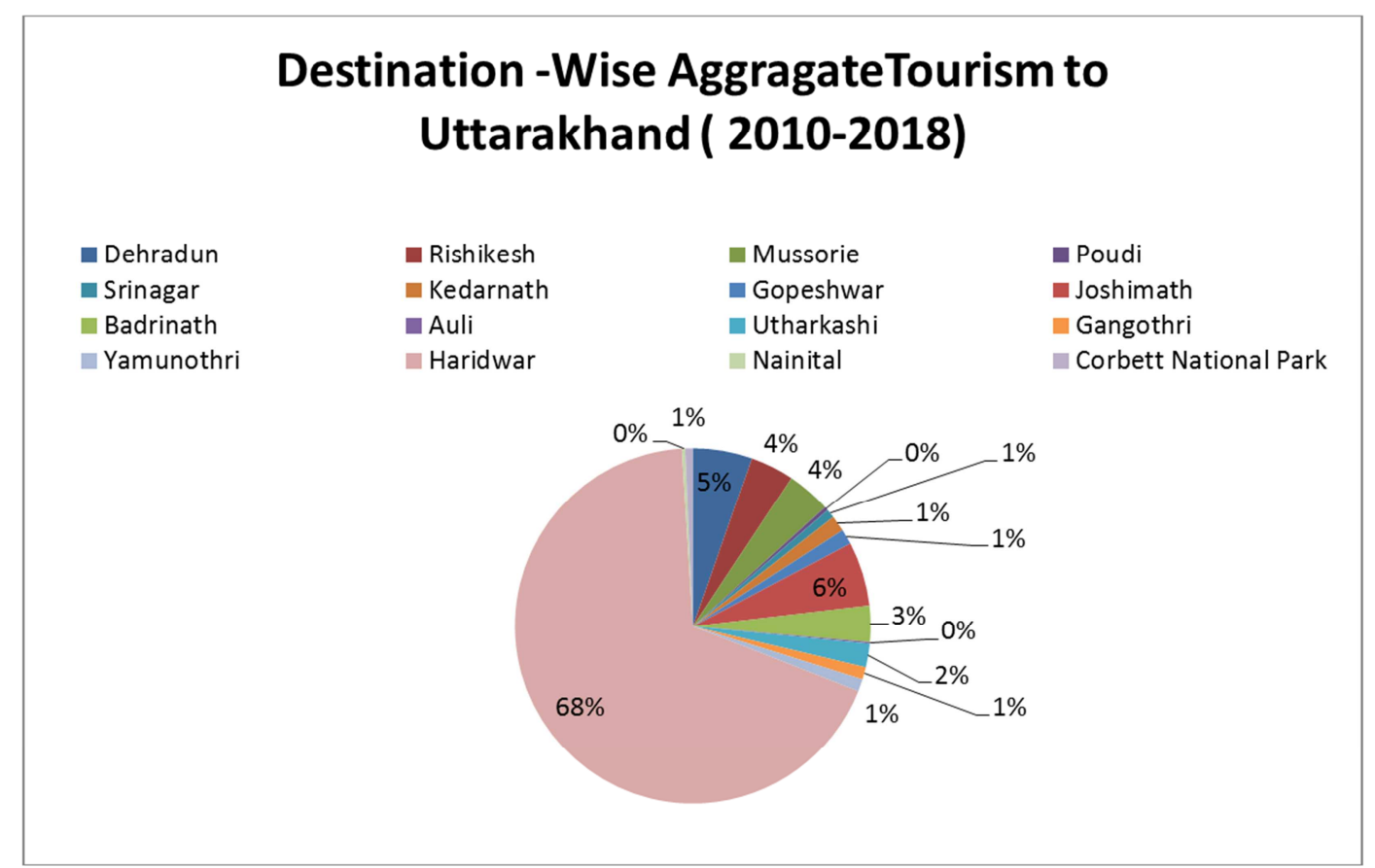

Figure 1. Destination-Wise Aggregate Tourism to Uttarakhand (2010-2018)

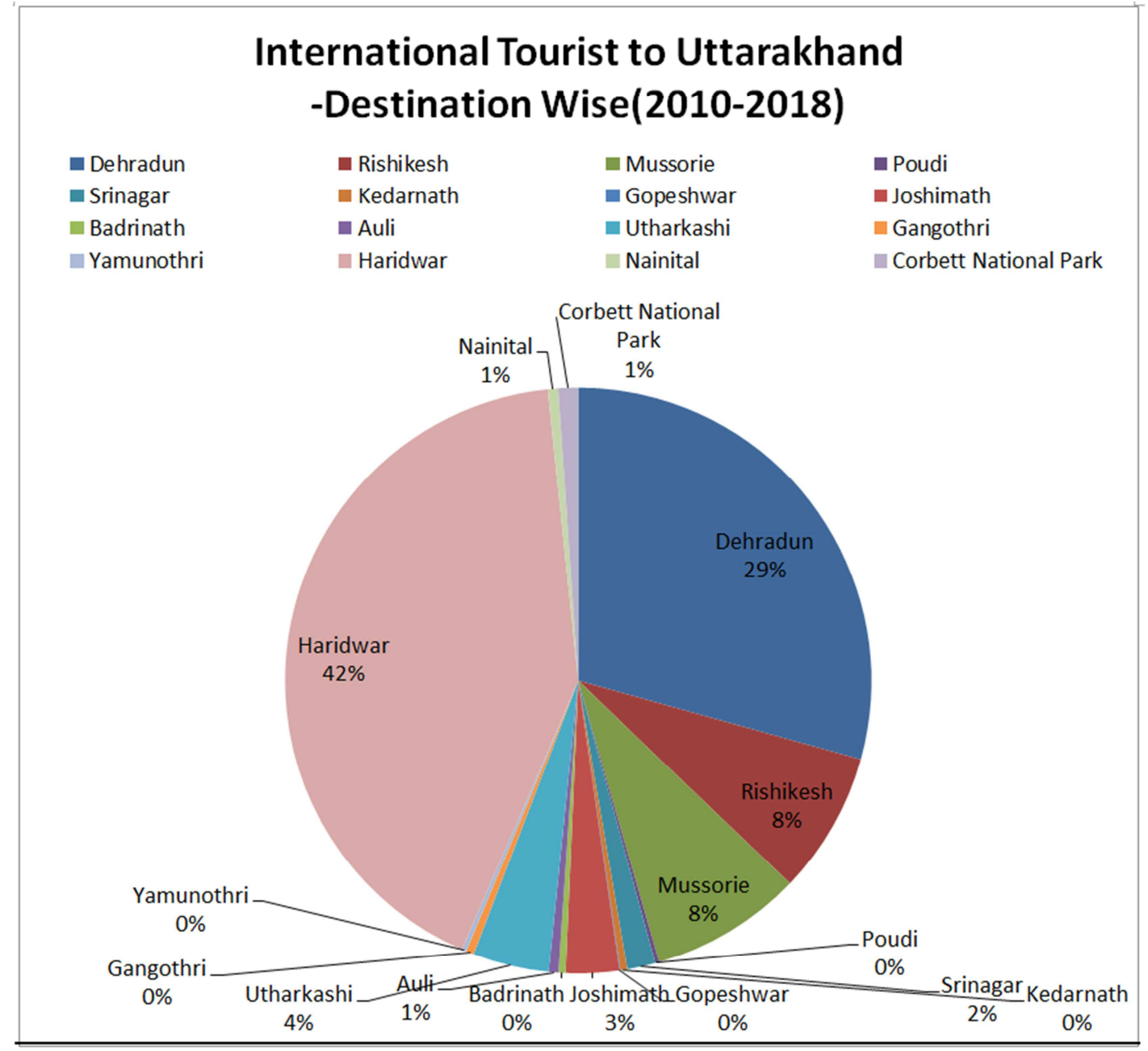

Figure 2. International Tourist to Uttarakhand-Destination Wise (2010-2018) 
Corbett has been a haunt for tourists and wildlife lovers for a long time. Tourism is only allowed in selected areas of Corbett Tiger Reserve so that people get an opportunity to see its landscape and wildlife. In recent years the number of people coming here has increased dramatically. Presently, every season more than 70,000 visitors come to the park.

Corbett National Park comprises $520.8 \mathrm{~km}^{2}$ (201.1 sq mi) area of hills, riverine belts, marshy depressions, grasslands and a large lake. The elevation ranges from 1,300 to $4,000 \mathrm{ft}$ (400 to $1,220 \mathrm{~m}$ ). Winter nights are cold but the days are bright and sunny. It rains from July to September.

Dense moist deciduous forest mainly consists of Sal, Haldu, Peepal, Rohini and Mango trees. Forest covers almost $73 \%$ of the park, $10 \%$ of the area consists of grasslands. It houses around 110 tree species, 50 species of mammals, 580 bird species and 25 reptile species.

Jim Corbett National Park is the oldest national park in India and was established in 1936 as Hailey National Park to protect the endangered Bengal tiger. It is located in Nainital district and Pauri Garhwal district of Uttarakhand and was named after Jim Corbett, a well known hunter and naturalist. The park was the first to come under the Project Tiger initiative. Corbett National Park is one of the thirteen protected areas covered by the World Wide Fund For Nature under their Terai Arc Landscape Program. The program aims to protect three of the five terrestrial flagship species, the tiger, the Asian elephant and the great onehorned rhinoceros, by restoring corridors of forest to link 13 protected areas of Nepal and India, to enable wildlife migration.[13]

\subsection{Distribution of Tourists (Visiting Uttarakhand) by Country/State of Origin}

Figures $3 \& 4$ shows the distribution of tourists by their country and state of origin. As far as foreign tourists are concerned the maximum percentage of tourists is from UK (24\%) followed by USA and France which contributes $16 \%$ of tourists to Jim Corbett national park. Russia and Belgium also contribute $8 \%$ tourists each. Tourists also come from Germany (4\%), Australia (4\%). Other countries contribute $8 \%$ of tourists to Jim Corbett National Park.

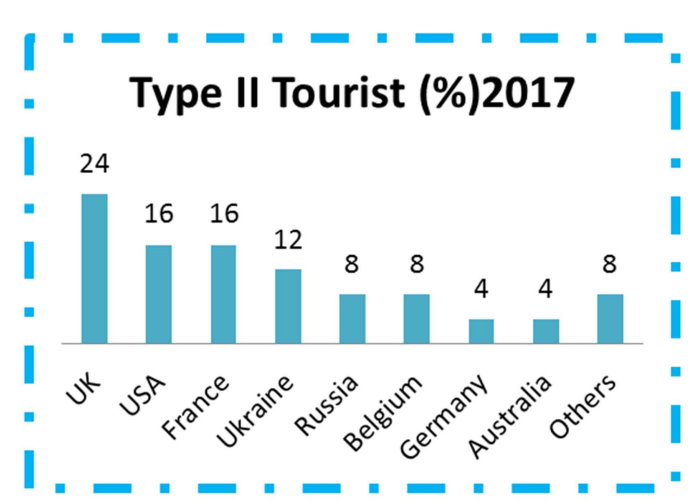

Figure 3. Type II Tourist(\%)2017.

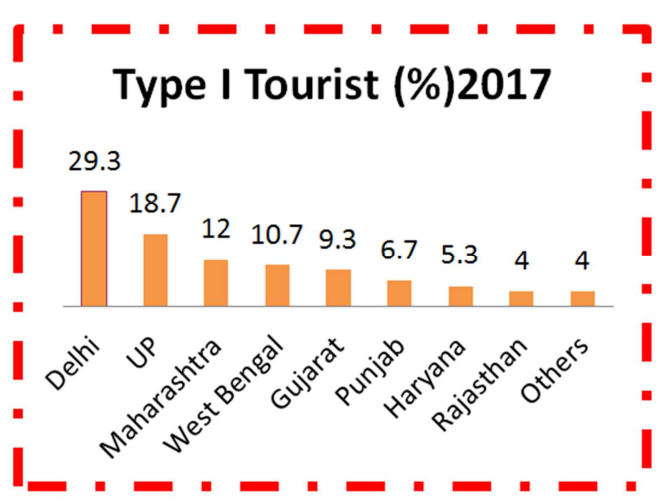

Figure 4. Type 1Tourist (\%) 2017.

Table 3. Demographic Distribution of Sample Tourist (100) Respondents.

\begin{tabular}{llll}
\hline S.N. & Demographic Variables & Category of Respondents & Frequency \\
\hline 1 & \multirow{3}{*}{ Type of Tourist } & Foreign & 25 \\
& & Domestic & 75 \\
& & Up to $10^{\text {th }}$ & 5 \\
& & Up to 12 & th \\
2 & \multirow{3}{*}{ Educational Qualification } & Graduation & 54 \\
& & Post Graduation & 30 \\
& & PhD and Above & 6 \\
& & Below 10 Lacs & 44 \\
& & 10-20 lacs & 24 \\
3 & Annual Income & 20-30 Lacs & 19 \\
& & $30-40$ Lacs & 7 \\
& & Above 40 Lacs & 6 \\
\hline
\end{tabular}

Source: Field Survey

Table 4. Typetourist $*$ catexpenditure Crosstabulation.

\begin{tabular}{|c|c|c|c|c|c|c|c|c|}
\hline & & \multicolumn{6}{|c|}{ Catexpenditure } & \multirow{2}{*}{ Total } \\
\hline & & below 20000 & 20001-40000 & $40001-60000$ & $60001-80000$ & $80001-100000$ & above 100000 & \\
\hline \multirow{2}{*}{ Domestic } & Count & 45 & 17 & 3 & 4 & 3 & 3 & 75 \\
\hline & $\%$ within catexpenditure & $95.7 \%$ & $77.3 \%$ & $60.0 \%$ & $66.7 \%$ & $50.0 \%$ & $21.4 \%$ & $75.0 \%$ \\
\hline \multirow[b]{2}{*}{ Foreign } & Count & 2 & 5 & 2 & 2 & 3 & 11 & 25 \\
\hline & $\%$ within Typetourist & $8.0 \%$ & $20.0 \%$ & $8.0 \%$ & $8.0 \%$ & $12.0 \%$ & $44.0 \%$ & $100.0 \%$ \\
\hline \multirow{3}{*}{ Total } & Count & 47 & 22 & 5 & 6 & 6 & 14 & 100 \\
\hline & \% within Typetourist & $47.0 \%$ & $22.0 \%$ & $5.0 \%$ & $6.0 \%$ & $6.0 \%$ & $14.0 \%$ & $100.0 \%$ \\
\hline & $\%$ within catexpenditure & $100.0 \%$ & $100.0 \%$ & $100.0 \%$ & $100.0 \%$ & $100.0 \%$ & $100.0 \%$ & $100.0 \%$ \\
\hline
\end{tabular}


Table 5. Tests of Between-Subjects Effects.

\begin{tabular}{lllllll}
\hline \multicolumn{2}{l}{ Dependent Variable: Expenditure } & & & & \\
\hline Source & Type III Sum of Squares & df & Mean Square & F & Sig. & Partial Eta Squared \\
\hline Corrected Model & $149075028660.184^{\text {a }}$ & 9 & 16563892073.354 & 15.591 & .000 & .609 \\
Intercept & 275873345312.192 & 1 & 275873345312.192 & 259.664 & .000 & .743 \\
Typetourist & 21320728664.616 & 1 & 21320728664.616 & 20.068 & .000 & .182 \\
Annualincome & 61132775851.949 & 4 & 15283193962.987 & 14.385 & .000 & .390 \\
Typetourist * Annualincome & 2485213954.555 & 4 & 621303488.639 & .585 & .674 & .025 \\
Error & 95618049034.656 & 90 & 1062422767.052 & & & \\
Total & 457071560396.000 & 100 & & & & \\
Corrected Total & 244693077694.840 & 99 & & & & \\
a. R Squared =.609 (Adjusted R Squared =.570) & & & & & \\
\hline
\end{tabular}

On observation it can be seen that there is a significant main effect of the type of tourist (Foreign or Domestic) on the Expenditure as:-

1) the $F$ value is significant $(p<0.05)$ Hence our first hypothesis is rejected.

Similarly there is also significant main effect of Annual income on per day expenditure as

$2)$ the $F$ value is significant $(p<0.05)$ Hence our second hypothesis is also rejected.

There is a non significant interaction between the Annual income and type of tourist on the per day expenditure

3) $\mathrm{F}=0.0803, \mathrm{p}>0.05$. Hence our third hypothesis is accepted.

A look at the profile plots also clearly explains the main effects and the interaction.

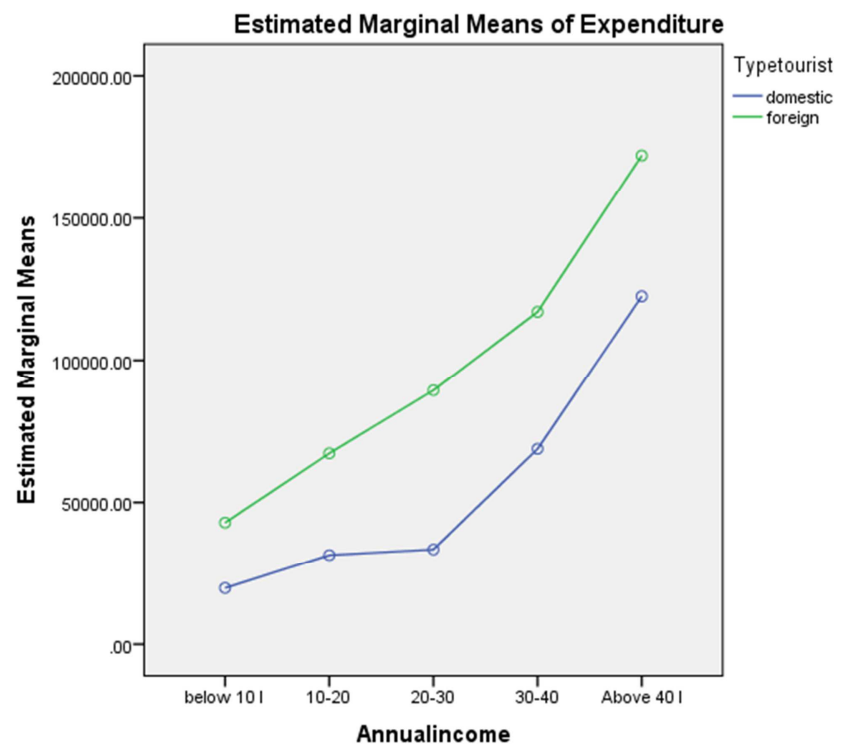

Figure 5. Estimated Marginal Means of Expenditure

The mean expenditure of foreigners is higher than that of domestic tourists which signifies that type of tourist is exerting significant effect. The means of expenditure across different categories of annual income of foreign tourists is higher than that of domestic tourists. As the annual income is rising the means of expenditure is also rising which shows that annual income is also exerting significant effect.

The interaction effect of both the independent variables is non significant as the lines are almost parallel to each other and do not cross anywhere.

\section{Findings}

Since:-

$\mathrm{TE}=\mathrm{f}\left(\mathrm{Y}_{\mathrm{d}}\right)$ Equation

$\mathrm{TE}=\mathrm{f}\left(\mathrm{F}_{\mathrm{t}}, \mathrm{D}_{\mathrm{t}}\right)$ Equation

$\mathrm{TE}={ }^{\prime} \mathrm{F}\left[\mathrm{Y}_{\mathrm{d}}\left(\mathrm{F}_{\mathrm{t}}, \mathrm{D}_{\mathrm{t}}\right)\right]$ Equality $>1<$

Where:

$\mathrm{TE}=$ Tourism Expenditure, $\mathrm{Y}_{\mathrm{d}}=$ Disposable Income, $\mathrm{F}_{\mathrm{t}}=$ Foreign Tourist, $\mathrm{D}_{\mathrm{t}}=$ Domestic Tourist

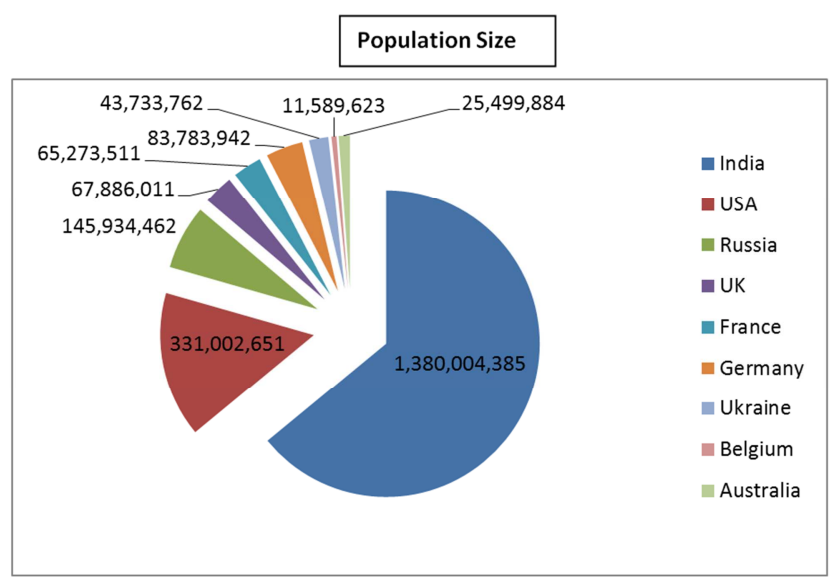

Figure 6. Population SIze [16]

What are the factors responsible for this huge gap across levels of income? Certainly these are family size at micro level and population size at the macro level.

Since most of Type II tourist come from highly developed nations (Figure 1) one of them being U.K. and of course U.S.A. who are known for vast territory and very low population size (Figure 4). It's obvious when family size is low --- size of future uncertainties also tend to be low; so their expenditure part becomes strong. Further, when population intercept is low and gross domestic product (GDP) is very high; then national expenditure component of these countries, out of the tax revenue, also becomes very high. Higher expenditure on fewer people reflects in the not only in sound civic amenities/ common infrastructure they avail in their respective countries; but also, in the financial and physical securities which they can reap at a relatively lower cost i.e. heavenly old age homes, health packages, personal care takers etc., anything related till the end of life-cycle. Herein lies the rationale of best and soft governance. While 
in India we think only in personal interest and personal welfare and continue expanding family size if not within the family then creating spectrum and strata: dependent variable, here, becomes passion for the institution of marriage; even if they don't have enough means of survival and revival across all strata of society.

So for the long term welfare of the national citizen it has now become pertinent to bring forth a change at attitudinal level. Because development can't alone occur only on the basis of GDP (Gross Domestic Product) rather this is ADP (Attitude of Persons) that calls forth development of human institution. Economic prosperity, at last, rests upon iconic prosperity which in turn lies not only on the educational quality but more importantly on human constitution which is the function of coupling herein lies the importance of right match of male and female to form the institution of marriage. So that even lesser number of people can produce as much as to give decent life not only to the dependents of their own nation, simultaneously, can create spread effect for the other nations also. When the peace will prevail all around; tourism in its true spirit will shine. Life is finite but the earth's beauty is infinite lets have everyone enough chance to perceive and conceive till synergies co-inside and energies revive; not for bloody revolutions rather to make blood relations. This will pave a way to make one nation, one world, one God Society: studded with good humans where neither country and race nor class and caste struggles play their role. This is the ultimate vision of our great philosophers and great "God Almighty".

\section{Conclusion and Suggestions}

Since annual income and tourist type have no association with regard to expenditure on tourism so it is strongly suggested to advertise [14] the benefits occurring through tourism. Since Indian mentality is largely based on frugality that needs to overcome.

People from middle income strata are skeptical about future well being in the absence of hefty savings; so there money is diverted towards savings which otherwise would have been invested for touring to and fro. So in order to raise their confidence level about future economic sustainability of their own-self state should act as catalyst. Proper tourism development policy is the need of the hour, and for this, the Govet. should do a thorough survey in the state.[15] Various schemes based on health -care, old age caretakers, funeral rituals not only should be implemented but also have variety, easier availability and made compulsory at least for those who come above certain income brackets and are state employees.

\section{References}

[1] Human Developmer Report (2019): Beyond income, beyond averages, beyond today: Inequalities in human development in the 21 st century, UNDP, AGS, USA.

[2] Keynes, J. M. (1930). Economic Possibilities for our Grandchildren. Essays in Persuasion, New York: Harcourt Brace.

[3] Smith, A. (1759). The Theory of Moral Sentiments. Adam Smith Istitute.

[4] Davidson, K. R. (1871). INTRODUCTION TO: HEGEL'S ENCYCLOPEDIA OF THE PHILOSOPHICAL SCIENCES. The Journal of Speculative Philosophy, Vol. 5, No. 3.

[5] Blackledge, P. (2008, October). Marxism and ethics. International Socialism.

[6] Cole, N. L. (2019, September 03). What Is Social Stratification, and Why Does It Matter?. Social Sciences.

[7] Domeckopol. (2018, July 16). Hegel - Freedom, stability, and social change. The Sociological Mail

[8] Agrawal, A. (2018). Development Strategy: The Seventh Heaven. Global Journal of Human Social Science: Economics, Vol 18 Issue 7.

[9] Helliwell, Huang, Wang, \& Norton(2020): Social Environments for World Happiness, World Happiness Report, SDSN, New York.

[10] Uttarakhand Economic Survey (2018-19), Directorate of economics and Statistics, Vol. II. page 62.

[11] Directorate Of Economics \& Statistics Planning Department, Government of UTTARAKHAND.

[12] Regional Tourism Satellite Account Uttarakhand (2015-2016): National Council of Applied Economic Research.

[13] Wikipedia: Jim Corbett National Park.

[14] Agrawal A. (2001): Tourism for Sustainable Development in Uttaranchal, Indian Journal of Marketing, Vol XXXI, No. 9-10.

[15] S. Malini and A. Agrawal (2020): Tourism Stimulator (A Case Study of Jim-Corbett), Economic Challenger: An International Journal, Vol. 22 (87), 21-30.

[16] Worldometer www.Worldometers.info. 